\title{
Effects of restricted suckling on forage intake of range calves
}

\author{
B.F. SOWELL, J.D. WALLACE, M.E. BRANINE, M.E. HUBBERT, E.L. FREDRICKSON, \\ AND J.G.P. BOWMAN
}

\begin{abstract}
Authors are assistant professor, Department of Animal and Range Sciences, Montana State University, Bozeman, Mont. 59717; retired professor, Department of Animal and Range Sciences, New Mexico State University, Las Cruces, N.M. 88003; nutritionist, Hoffman LaRoche, Inc., Parker, Colo. 80103; nutritional consultant, Hubbert Biological Systems, Plattsmouth, Nebr. 68048; research scientist, Agricultural Research Service, Jornada Experimental Range, Las Cruces, N.M. 88003; and assistant professor, Department of Animal and Range Sciences, Montana State University, Bozeman, Mont. 59717.
\end{abstract}

\begin{abstract}
Twenty two-year-old primiparous Angus $\times$ Hereford cows and their heifer calves were used to study effeets of milk consumption on calf performance, suckling behavior, and forage intake. Ten cow-calf pairs were allotted to each of 2 treatments on blue grama (Bouteloua gracilis [H.B.K.] Lag.) rangeland. Calves from 5 cows were prevented from suckling the rear udder quarters for 4 weeks to reduce milk intake by $32 \%$ when calves averaged $71 \pm$ 4 days of age. The other 5 calves were allowed to suckle normally. Four 12-day sampling periods were conducted from June through September. Calves from the control treatment weighed more $(\mathbf{P}<\mathbf{0 . 0 5 )}$ than restricted calves in each period and at weaning. Calves from the restricted treatment did not $(P>0.10)$ suckle longer or more frequently than control calves during any sampling period. Forage organic matter intake was not $(\mathbf{P}>0.10)$ different between cows or calves from either group at any date. Milk production was not different $(P>0.10)$ between groups 1 month after restriction periods were terminated. Calves on 4 week milk restriction did not increase forage organic matter intake and had decreased weaning weights compared to control animals.
\end{abstract}

Key Words: milk restriction, milk intake, cow, bchavior, blue grama, buffalograss, rangelands

Inconsistent results have been reported concerning the influence of milk intake on calf performance and forage intake (Baker et al. 1976, Lusby et al. 1976). Effects of early weaning, temporary calf removal or restricted suckling on forage intake and performance by calves appear to be mediated by length of separation interval and quality of available feed (Neville and McCormick 1981, Odde et al. 1986, Wettemann et al. 1987). Le Du et al. (1976) concluded that forage intake of calves increased as milk intake declined. Broesder et al. (1990) found that a reduction in milk replacer consumed by male Holstein calves resulted in a linear increase in forage organic matter intake of long stemmed

Contribution No. J-4033 from Montana Agr. Exp. Station.

Manuscript accepted 6 June 1995. alfalfa hay, but total organic matter intake was not changed. Most studies have examined forage and milk intake relationships of calves on improved pastures or other high quality forages. Our objective was to measure the effects of suckling restriction on cow and calf weights, suckling behavior, and forage intake on blue grama (Bouteloua gracilis [H.B.K.] Lag)-buffalograss (Buchloe dactyloides Nutt.) rangelands.

\section{Materials and Methods}

\section{Research Site}

Ten two-year-old Angus $\times$ Hereford primiparous cows (average initial weight $=316 \mathrm{~kg}$ ) and their March $\cdot$ born heifer calves were maintained on a 36-ha pasture at the Clayton Livestock Research Center located in northeastern New Mexico. Vegetation on the study pastures was dominated by blue grama, buffalograss, tobosagrass (Hilaria mutica [Torr.] Benth.), and threeawns (Aristida spp. Nutt.). Major forbs include scarlet globemallow (Sphaeralcea coccinea [Pursh.] Rydb.), and locoweeds (Astragalus spp. Wood). Average annual precipitation during the study year was $16 \%$ above normal $(36 \mathrm{~cm})$. Rainfall in May and June appeared adequate to initiate forage growth, but July precipitation was only $31 \%$ of normal.

\section{Sampling Procedures}

In late March, calves (average age $=31 \pm 5$ days) were branded, dehorned and vaccinated against malignant edema and blackleg. Five cow-calf pairs were randomly assigned to 1 of 2 treatments. Udder covers were placed on the cows' posterior quarters to reduce milk intake $32 \%$ for a total of 28 days. Average calf age was $52 \pm 4$ days when milk restriction was initiated. Calves were restricted for 14 days, evaluated for 9 days, and restricted for another 14 days. Restricted calves were $89 \pm 4$ days of age when milk restriction was terminated. The other 5 calves received no milk restriction and served as controls. Water and plain salt were available at all times on the 12-ha study pasture where intake measurements were collected.

Four 12-diay sampling periods were conducted from 6 to 18 June, 5 to $17 \mathrm{July}, 2$ to 14 August, and 24 September to 5 
October. The June sampling period included the last 12 days of the 28 day suckling restriction. Calves averaged 76, 106, 137, and 184 days of age at the beginning of each sampling period, respectively.

Grazing and suckling behavior of cows and calves (Williams et al. 1977) were recorded from sunrise to sunset $(0600$ to 1900 hours) during the first day of each sampling period. Animal activities were identified as grazing, standing, lying, walking, or drinking, and recorded every 15 minutes for all animals. The total grazing time for each animal was tabulated for the day. Nursing frequency (events/days) and duration (minutes/event) of each suckling event was recorded.

Milk intake estimates, and cow and calf body weight (deprived of food and water for 12 hours) were measured prior to initiation of treatments and at the beginning and end of each sampling period. On the second day of each sampling period, cows and calves were allowed to nurse for 1 to 2 hours, and then separated for 12 hours. The next morning 24 hour milk intake was estimated by the weigh-suckle-weigh technique (Williams et al. 1977).

Cows and calves were dosed with chromium sesquioxide $\left(\mathrm{Cr}_{2} \mathrm{O}_{3}\right)$ powder in gelatin capsules once daily for 10 days beginning on the third day of each sampling period to estimate fecal output. Ten g/day of $\mathrm{Cr}_{2} \mathrm{O}_{3}$ were administered to each cow, and calves were dosed with 5,6 , and $7 \mathrm{~g} /$ day of $\mathrm{Cr}_{2} \mathrm{O}_{3}$ during the 4 respective sampling periods to account for body weight changes over time. After a 5 day equilibration period, fecal grab samples were collected once daily over 5 days beginning on the 8th day of each sampling period. Fecal output was calculated by dividing the amount of $\mathrm{Cr}$ dosed by $\mathrm{Cr}$ concentration in fecal organic matter.

Three esophageally cannulated steers (average body weight $=$ $541 \mathrm{~kg}$ ) were used to collect masticate samples twice daily during 3 days of each sampling period. Collections were taken at 0730 and 1800 hours, when cows and calves were grazed intensely. Masticate samples were composited across days and steers, and lyophilized.

At the end of each sampling period, in vitro dry matter disappearance (two-stage; Tilley and Terry 1963) of the composited masticate was measured using strained rumen fluid from 2 ruminally cannulated steers fed native prairie hay. Fecal organic matter output divided by masticate indigestibility was used to estimate forage organic matter intake for each animal during each sampling period. Calf fecal organic matter was adjusted to remove the effects of milk organic matter according to Peischel (1980). Milk was assumed to contain $90 \%$ organic matter (Peischel 1980) and milk indigestibility was assumed to be $3.53 \%$ (Blaxter and Wood, 1952): The adjusted calf fecal organic matter was divided by forage indigestibility to provide an estimate of forage organle matter intake.

Pasture vegetation was clipped by plant species to approximately $2 \mathrm{~cm}$ above the ground using 80 to 150 circular wire frame $\left(.2 \mathrm{~m}^{2}\right)$, dried at $50^{\circ} \mathrm{C}$ for 48 hours, and weighed to estimate available standing crop (kg/ha) of blue grama/ buffalograss, forbs, and other species during each sampling period.

\section{Laboratory Analyses}

After lyophilization, esophageal masticate samples were ground to pass a 2-mm screen in a Wiley mill, and analyzed for dry matter, nitrogen (N), ash (AOAC 1984), neutral detergent fiber, acid detergent fiber, and acid detergent lignin (Goering and
Van Soest 1970). Available N was calculated as the difference between total $\mathrm{N}$ and nonavailable $\mathrm{N}$, which was determined by Kjeldahl $\mathrm{N}$ analysis of acid detergent fiber residue.

Fecal samples were dried at $50^{\circ} \mathrm{C}$, ground to pass a $2-\mathrm{mm}$ screen, compared on an equal dry weight basis across days within each sampling period for each animal, and analyzed for dry matter, ash (AOAC 1984), and Cr (Williams et al. (1962).

\section{Statistical Analysis}

Analysis of variance was conducted using GLM procedures of SAS (1988). Grazing behavior, body weight, milk intake, and forage organic matter intake data were analyzed as a split-plot design, with treatment as the main plot and sampling period as the subplot (Gill and Hafs 1971). Treatment effects were tested using animals within treatment as the error term. As a result of treatment $x$ period interactions for several variables $(P<0.05)$, data are presented for each sampling period.

\section{Results and Discussion}

\section{Standing Crop}

Mean standing crop estimates of the study pasture are presented in Table 1. Total standing crop peaked in July and August, and declined in September. Blue grama and buffalograss production was greatest in July and least in August. Forb production was greatest in August when rainfall was abundant. Funk et al. (1987) reported steers grazing the same study pasture consumed $78 \%$ grasses ( $38 \%$ blue grama and buffalograss) and $22 \%$ forbs during a similar summer grazing period.

Table 1. Standing crop on blue grama-buffalograss rangeland throughout the grazing season.

\begin{tabular}{llllc}
\hline Item & June & July & August & September \\
\hline $\begin{array}{l}\text { Number of quadrats } \\
\text { Blue grama/ }\end{array}$ & 80 & 105 & 145 & 150 \\
buffalograss, kg/ha & 403 & 488 & 287 & 300 \\
Forbs, kg/ha & 107 & 141 & 284 & 42 \\
Other, $\mathrm{kg} / \mathrm{ha}$ & 247 & 189 & 231 & 215 \\
Total, $\mathrm{kg} / \mathrm{ha}$ & $757 \pm 301^{\mathrm{a}}$ & $818 \pm 433$ & $802 \pm 592$ & $557 \pm 304$ \\
\hline
\end{tabular}

${ }^{a}$ Standard error of the mean.

\section{Diet Quality}

In vitro organic matter digestibility (Table 2$)$ did not differ $(\mathrm{P}>$ 0.05 ) between sampling periods. Diet $N$ content and available $N$ were low throughout the summer and were influenced $(\mathrm{P}<0.05)$ by sampling period. Dietary $N$ and available $N$ were lowest $(P<$ $0.05)$ in July and August and increased $(P<0.05)$ in September. Available $\mathrm{N}$ as a percentage of total $\mathrm{N}$ remained constant $(\mathrm{P}>$ 0.10) throughout the sampling periods, which agrees with McCollum and Galyean (1985), and Funk et al. (1987).

Ansotegui et al. (1991) found that diets selected by suckling calves were higher in $\mathrm{N}$ than diets selected by cows during certain months. A recent study by Grings et al. (1995) found calves selected diets which were $21 \%$ higher in crude protein and contained 5\% less neutral detergent fiber when compared to mature steers in June and July. They failed to detect any differences in diet quality between suckling calves and mature steers when forage quality declined in September. Diet chemical composition 
Table 2. Composition of esophageal extrusa from steers grazing blue grama-buffalograss rangeland from June through September.

\begin{tabular}{|c|c|c|c|c|c|}
\hline Item & June & July & August & September & SE \\
\hline In vitro organic matter disappearance, $\%$ & 59.5 & 52.2 & 55.2 & 54.3 & 1.7 \\
\hline $\mathrm{N}, \%$ of organic matter & $1.22^{\mathrm{b}}$ & $.97^{\mathrm{a}}$ & $1.11^{\mathrm{ab}}$ & $1.38^{b}$ & .1 \\
\hline \multicolumn{6}{|l|}{ Available N } \\
\hline $\mathscr{\%}$ of total $N$ & 82.4 & 79.5 & 80.6 & 83.5 & 1.3 \\
\hline Neutral detergent fiber, $\%$ of organic matter & 74.9 & 78.6 & 79.0 & 74.5 & 2.3 \\
\hline
\end{tabular}

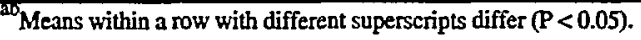

values as collected with steers in this study, may not be representative of cow or calf diets, but it was not possible to esophageally cannulate cows or calves for the purposes of this study. It is possible that diets selected by suckling calves and mature steers in this study were similar since forage quality was low (average neutral detergent fiber $=77 \%$ ) and there were no differences in in vitro organic matter disappearance, available $\mathrm{N}$, neutral detergent fiber, or acid detergent fiber between sampling periods.

Dietary neutral detergent fiber, acid detergent fiber, and acid detergent, lignin did not change $(\mathrm{P}<0.10)$ during the sampling periods. These findings are consistent with those of Funk et al. (1987).

\section{Calf Feeding Behavior}

Calves on restricted milk intake spent more $(P<0.05)$ time grazing than control calves in June (Table 3). Although restricted calves were suckling only the anterior quarters in June, there were no differences $(P>0.10)$ in nursing frequency or duration between groups. Williams et al. (1977) reported that calves nursed 3.2 to 3.5 times during 14 to 16 hours of daylight in early lactation. Wyatt et al. (1977) found that cows nursed single or twin calves approximately 3.4 to 4.4 times/day and nursed them for 8.8 to 9.9 minutes/suckling event, respectively. Odde et al. (1986) reported suckling restriction did not affect suckling frequency or duration 2 weeks after the restriction was concluded. Cross-nursing was not observed during any of the sampling periods in our study.

\section{Cow Intake and Weight}

No differences $(P>0.10)$ in body weight between restricted and control cows were detected during any sampling period (Table 4). Cows gained weight in all periods except August. Forage organic matter intake of restricted cows was not different $(P>0.10)$ from control cows during any period. Wyatt et al. (1977) found that cows producing different amounts of milk and rearing 1 or 2 calves consumed similar amounts of forage per day. Estimated forage organic matter intakes in the present study were greater than those reported for lactating Angus $\times$ Hereford cows $(19 \mathrm{~g} / \mathrm{kg}$ body weight) grazing blue grama rangelands by Rosiere et al. (1980), but almost identical to those ( $26 \mathrm{~g}$ organic matter $/ \mathrm{kg}$ body weight) reported by Funk et al. (1987) for steers grazing the same study pasture.

\section{Calf Intake and Weight}

Milk intake by restricted calves was $32 \%$ lower than that of control calves when udder covers were in place (Table 4). There were no differences $(P>0.10)$ in milk intake between restricted and control calves before or after the restriction interval. Milk intake of both groups declined throughout the grazing season. Peischel (1980), and Holloway and Butts (1983) noted similar declines in milk yields from parturition to weaning in other beef cattle breeds. Body weights of control calves were greater $(\mathrm{P}<$ 0.05 ) than weights of restricted calves after 4 weeks of milk restriction (Table 4$)$, and remained higher $(P<0.05)$ through all sampling periods. Neville (1962) indicated that the relationship between milk intake and calf weight gain was greatest during the first 60 days of the calf's life. Calves weaned at 30 to 60 days of age, and provided with high concentrate diets, were similar in weight at 205 days of age to calves weaned at 205 days (Richardson et al. 1978, Lusby et al. 1981). Results from the present study indicate that weaning weights of calves grazing blue grama rangelands were adversely affected by reducing milk intake $32 \%$ for 4 weeks.

Estimates of forage organic matter intake by control calves were not different $(\mathrm{P}<0.10)$ from those of restricted calves during any period (Table 4). Reduction $(\mathrm{P}<0.05)$ in weight of restricted calves when udder covers were in place suggests that calves did not increase forage organic matter intake in response to decreased milk intake. Peishel (1980) reported that forage intake by calves raised on native Kansas range was not influenced by milk consumption. Lusby et al. (1976) found that non-

Table 3. Grazing time, nursing frequency and duration of control (Con.) and restricted (Res.) calves from June through September.

\begin{tabular}{|c|c|c|c|c|c|c|c|c|c|}
\hline \multirow{2}{*}{$\begin{array}{l}\text { Month } \\
\text { Item }\end{array}$} & \multicolumn{2}{|c|}{ June } & \multicolumn{2}{|c|}{ July } & \multicolumn{2}{|c|}{ August } & \multicolumn{2}{|c|}{ September } & \multirow[b]{2}{*}{ SE } \\
\hline & Con. & Res. & Con. & Res. & $\overline{\text { Con. }}$ & Res. & Con. & Res. & \\
\hline Nursing frequency, times/day & 3.6 & 3.4 & 4.0 & 3.6 & 2.6 & 3.4 & 1.8 & 1.2 & .3 \\
\hline Observation time, hours & 12 & & 14 & & 14 & & 12 & & \\
\hline
\end{tabular}

${ }^{a b}$ Means within a row and month with different superscripts differ $(P<0.05)$. 
Table 4. Body weight, forage intake and milk intake of restricted (Res.) and control (Con.) cows and calves grazing blue grama rangeland from June through September.

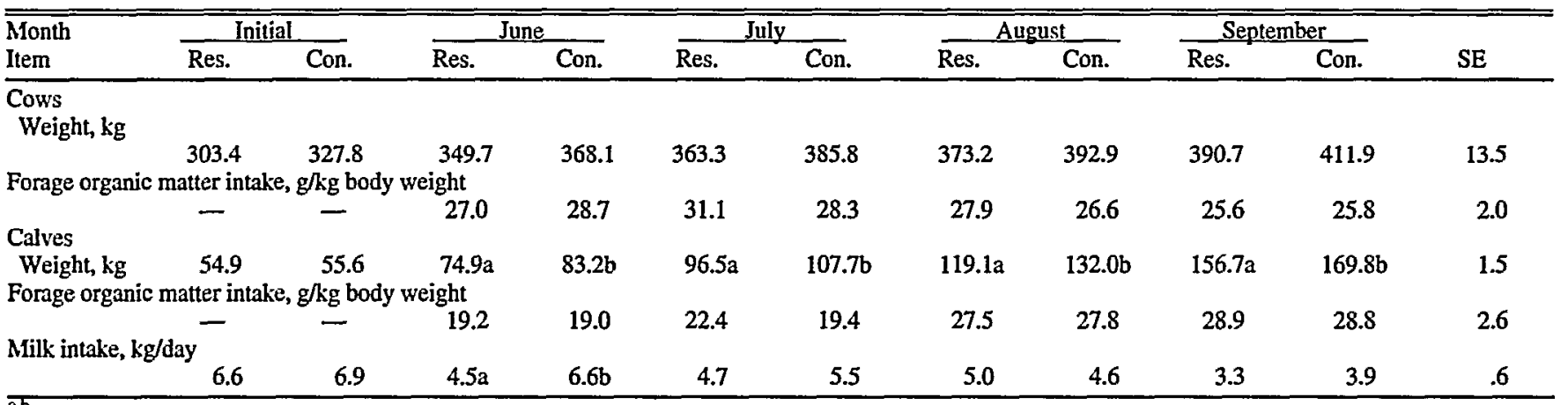

a,b Means within a row and month with different superseripts differ $(\mathrm{P}<0.05)$.

milk nutrient intake, non-milk nutrient digestibility, milk intake and calf body weight (reflecting age) were interrelated. Calves of similar ages ( 53 to 150 days of age) with access to high quality diets were able to increase forage intake rapidly in response to decreased milk intake (Le Du et al. 1976, Lusby et al. 1976, Baker et al. 1976, Boggs et al. 1980, Broesder et al. 1990 , Ansotegui et al. 1991). Intake values collected on this study are very similar to those reported by Funk et al. (1987) for steers grazing the same pasture.

\section{Conclusions}

Previous studies have suggested that reduction in milk intake leads to increases in forage intake by young calves, and that calves suckling low-milk-producing cows consume more forage than calves suckling high-milk producing cows. Data from this study suggest that young calves (75 days of age), grazing blue grama rangelands (average neutral detergent fiber $=77 \%$ ), were not able to increase forage organic matter intake when milk intake was restricted. This would imply that forage intake by cilves grazing low-quality pastures is limited by bulk fill.

\section{Literature Cited}

Ansotegui, R.P., K.M. Havstad, J.D. Wallace, and D.M. Hallford. 1991. Effects of milk intake on forage intake and performance of suckling range calves. J. Anim. Sci. 69:899-904.

AOAC. 1984. Official Methods of Analysis (14th Ed.). Association of Official Analytical Chemists, Arlington, Virg.

Baker, R.D., Y.L.P. Le Du, and J.M. Barker. 1976. Milk-fed calves. 1. The effects of milk intake upon the herbage intake and performance of grazing calves. J. Agr. Sci. (Camb.) 87:187-196.

Blaxter, K.L. and W.A. Wood. 1952. The nutrition of the young Ayrshire calf. 5. The nutritive value of cow's whole milk. Brit. J. Nutr. 1:1-19.

Boggs, D.L., E.F. Smith, R.R. Schalles, B.E. Brent, L.R. Corah, and R.J. Pruitt. 1980. Effects of milk and forage intake on calf performance. J. Anim. Sci. 51:550-553.

Broesder, J.T., J.B. Judkins, L.J. Krysl, S.A. Gunter, and R.K. Barton. 1990. Thirty or sixty percent milk replacer reduction for calves: Effects on alfalfa hay intake and digestibility, digestive kinetics and ruminal fermentation. J. Anim. Sci. 68:2974-2985.

Funk, M.A., M.L. Galyean, M.E. Branine, and L.J. Krysl. 1987. Steers grazing blue grama rangeland throughout the growing season. I. Dietary composition, intake, digesta kinetics and ruminal fermentation. J. Anim. Sci. 65:1342-1353.

Gill, J.L. and H.D. Hafs. 1971. Analysis of repeated measurements of animals. J. Anim. Sci. 33:331-336.
Goering, H.K. and P.J. Van Soest. 1970. Forage fiber analyses (apparatus, reagents, procedures and some applications). Agr. Handb. No. 379. ARS, USDA, Washington, DC.

Grings, E.E. D.C. Adams, and R.E. Short. 1995. Diet quality of suckling calves and mature steers on Northern Great Plains rangelands. J. Range Manage. 48:438-441.

Holloway, J.W. and W.T. Butts. 1983. Patterns of forage intake, milk yield, calf growth and efficiency of Angus cow-calf pairs grazing fescue-legume or fescue pastures. Univ. Tenn. Agr. Exp. Sta. Bull. 621.

Le Du, Y.P.L., R.D. Baker, and J.M. Barker. 1976. Milk-fed calves. 2. The effect of length of milk feeding period and milk intake upon herbage intake and performance of grazing calves. J. Agr. Sci. (Camb.). 87:197-204.

Lusby, K.S., D.F. Stephens, and R. Totusek. 1976. Effects of milk intake by nursing calves on forage intake on range and creep intake and digestibility in drylot. J. Anim. Sci. 43:1066-1071.

Lusby, K.S., R.P. Wettemann, and E.J. Turman. 1981. Effects of early weaning calves from first-calf heifers on calf and heifer performance. $J$. Anim. Sci. 53:1193.

McCollum, F.T. and M.L. Galyean. 1985. Cattle grazing blue grama rangeland. II. Seasonal forage intake and digesta kinetics. J. Range Manage. 38:543-546.

Neville, W.E. 1962. Influence of dam's milk production and other factors on 120-and 240-day weight of Hereford calves. J. Anim. Sci. 21:315-320.

Neville, W.E. and W.C. McCormick. 1981. Performance of early- and normal-weaned beef calves and their dams. J. Anim. Sci. 52:715-724.

Odde, K.G., G.H. Kiracofe, and R.R. Schalles. 1986. Effect of forty-eight hour calf removal, once-or-twice-daily suckling and norgestomet on beef cow and calf performance. Theriogenology 26:317-381.

Peischel, H.A. 1980. Factors affecting milk and grass consumption of calves grazing native range. Ph.D. Diss. Kansas State Univ., Manhattan, Kans.

Richardson, F.D., J. Oliver, and G.P.Y. Clarke. 1978. The pre-weaning and post-weaning growth of beef calves in relation to the amounts of milk and solid food consumed during the suckling period. Rhod. J. Agr. Res. 16:97-108.

Rosiere, R.E., J.D. Wallace, and R.D. Pieper. 1980. Forage intake in twoyear old cows and heifers grazing blue grama summer range. J. Range Manage. 33:71-73.

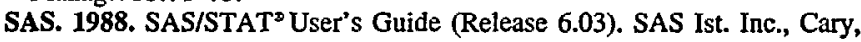
N.C.

Tilley, J.M.A and R.A. Terry. 1963. A two stage technique for the in vitro digestion of forage crops. J. Brit. Grassl. Soc. 18:104-111.

Wettemann, R.P., K.S. Lusby, and G.E. Selk. 1987. Influence of 96 hour calf separation on reproductive performance of range cows. p. 67-69. Oklahoma Agr. Exp. Sta. MP-119.

Williams, C.H., D.J. David, and O. Iismaa. 1962. The determination of chromic oxide in faeces samples by atomic absorption spectrophotometry. J. Agr. Sci. (Camb.). 59:381-385.

Williams, J.H., D.C. Anderson, and D.D. Kress. 1977. Nursing behavior in young Hereford calves. Proc. West. Sec. Amer. Soc. Anim. Sci. 28:35-36.

Wyatt, R.D. M.B. Gould, and R. Totusek. 1977. Effects of single vs simulated twin rearing on cow and calf performance. J. Anim. Sci. 45:1409-1414. 